\title{
ANALISIS KINERJA 14 REKSA DANA SAHAM TERBAIK PERIODE 2010
}

\author{
Yen Sun \\ Jurusan Akuntansi, Fakultas Ekonomi dan Bisnis, Bina Nusantara University \\ Jln. K.H. Syahdan No. 9, Kemanggisan, Palmerah, Jakarta Barat 11480 \\ ysun@binus.edu
}

\begin{abstract}
Capital Market is a significant indicator of an economy for a country. However, in Indonesia many people are not familiar yet with the investment activity in capital market. The writer is then interested to study the performance of the best (15) mutual fund (shares) 2010 version of Investor Magazine for the next period investment decision in 2011. The research will be focused on several stages. First, it will compute the return for 14 mutual funds, market return and risk-free rate for one year period. Then, the performance will be evaluated using Sharpe, Treynor to find which mutual fund outperform the market. Also, each method will result rank of the best mutual fund. Furthermore, there is one more method will be used in performance evaluation, Jensen. The result of this study is there are two mutual funds that can be recommended for investment in 2011, they are Panin Dana Maksima and Panin Dana Prima. They are recommended because the two mutual funds showed the best performance for those three methods of evaluation and they can maintain their performance for more than one period.
\end{abstract}

Keywords: capital market, economy, shares, evaluation

\begin{abstract}
ABSTRAK
Pasar modal memegang peranan yang cukup penting dalam perekonomian suatu negara, yaitu antara lain sebagai sarana sumber pendanaan bagi perusahaan, sarana untuk masyarakat dalam berinvestasi. Kemudian penulis tertarik untuk melakukan penelitian atas kinerja 15 reksa dana saham terbaik 2010 (menurut Majalah Investor yang terbit bulan Maret 2010 sehingga data mereka berdasarkan NAB 2009) untuk periode berikutnya yaitu data NAB tahun 2010 untuk keputusan investasi di 2011. Data yang akan digunakan adalah data harian NAB yang akan dievaluasi dan dianalisa untuk periode setahun mulai 1 Januari - 31 Desember 2010. Penelitian ini akan berfokus pada beberapa tahapan. Tahap pertama, mencari return ke 14 reksa dana, IHSG dan BI rate untuk periode setahun, setelah itu kinerja reksa dana akan dievaluasi menggunakan metode Sharpe, Treynor untuk menentukan rangking reksa dana terbaik yang dapat outperform market. Selain kedua metode tersebut, evaluasi lain yang akan digunakan adalah Jensen performance. Hasil dari penelitian ini adalah ada dua reksa dana yang dapat direkomendasikan untuk investasi di tahun 2011 yaitu Panin Dana Maksima dan Panin Dana Prima, karena keduanya menunjukkan hasil yang bagus untuk ketiga metode evaluasi dan mereka juga dapat mempertahankan kinerja mereka untuk periode lebih dari satu tahun.
\end{abstract}

Kata kunci: pasar modal, ekonomi, saham, evaluasi 


\section{PENDAHULUAN}

Ada beberapa peranan penting pasar modal bagi perekonomian suatu negara, yaitu menggerakkan perekonomian suatu negara karena merupakan sumber pendanaan bagi perusahaan, tempat atau sarana bagi masyarakat untuk berinvestasi, sebagai sarana bagi pemerataan pendapatan masyarakat karena masyarakat berkesempatan untuk menikmati keuntungan dari membeli saham walaupun tidak mendapat kesempatan untuk mengelola atau menjadi pemilik perusahaan. Selain itu, pasar modal juga sebagai indikator pertumbuhan atau keterpurukan ekonomi suatu negara bahkan pergerakannya memberikan efek domino antar satu negara ke negara lainnya. Seperti, pada saat US Subprime Crisis terjadi pada tahun 2008, beberapa bank dan investment bank collaps, memicu kepanikan di dunia pasar modal. Terjadilah gelombang panic selling yang mengakibatkan bursa saham wall street terus melorot tajam. Dow Jones Indeks menurun tajam ke angka terburuknya dalam 4 tahun terakhir. Keterpurukan pasar modal Amerika ini menimbulkan efek domino ke negara lainnya. seperti, pasar modal London menurun sebanyak $8 \%$ hanya dalam sehari, demikian pula dengan Jerman dan Perancis yang masing-masing mengalami penurunan pasar modal sebesar $7 \%$ dan $9 \%$. Bahkan efeknya juga sampai ke negara emerging market seperti Rusia, Brazil yang bursa sahamnya mengalami keterpurukan sampai dengan 15\%. Begitupula dengan India 52\%, China 57\% dan Indonesia $41 \%$.

Krisis US 2008 itu telah berdampak juga ke Indonesia, namun ternyata dampaknya tidak separah yang telah diperkirakan karena di tahun 2009 ekonomi Indonesia sudah membaik bahkan mengalami pertumbuhan ekonomi yang positif dan menjadi negara dengan pertumbuhan ekonomi tertinggi ketiga setelah China dan India di Asia. Hal ini juga didukung dengan perkembangan pasar modal di Indonesia, yaitu pada tahun 2009, Jakarta Composite Index memiliki pertumbuhan yang paling tinggi di Asia Tenggara yaitu sebesar 43,9\%, mengalahkan kenaikan index Singapore (27\%), Thailand $(26,8 \%)$ dan Malaysia (20,3\%). Walaupun pasar modal di Indonesia berkembang pesat, namun ada beberapa kendala besar yang harus dihadapi yaitu besarnya pengaruh investor asing terhadap pergerakan pasar di Indonesia. Di mana setiap pergerakan/movement dari investor asing cenderung akan diikuti oleh investor domestik. Di samping itu, jumlah domestic investor yang berpartisipasi di pasar masih sangat sedikit jika dibandingkan dengan jumlah populasi yang ada di Indonesia yaitu sebanyak \pm 300.000 investor (atau hanya sekitar $0.1 \%$ dari jumlah populasi). Jumlah ini sangat sedikit jika dibandingkan dengan negara-negara Asia Tenggara lainnya seperti Singapore (30\% investor dibandingkan jumlah populasinya) dan Malaysia (12,8\%) (Sadewa, 2009).

Melihat betapa pentingnya peranan pasar modal terhadap kondisi dan pertumbuhan ekonomi suatu negara, maka Indonesia perlu mengatasi kendala yang dihadapi oleh pasar modalnya, yaitu dengan cara menambah jumlah investor domestik yang berpartisipasi dalam kegiatan pasar modal dan mengedukasi mereka cara berinvestasi yang lebih baik sehingga tidak terlalu terpengaruh dengan pergerakan investor asing. Kecenderungan tipe investor domestik di Indonesia adalah tipe risk-averse investor. Di mana, mereka lebih tertarik untuk berinvestasi pada aset yang risk free seperti deposito di bank atau yang sedikit lebih beresiko tapi memberikan return yang lebih tinggi pula seperti properti. Mereka belum familiar dengan investasi yang memberikan return yang tinggi namun dengan resiko yang tinggi pula seperti investasi saham. Melihat tipe investor semacam ini, maka dapat ditarik kesimpulan bahwa di Indonesia perlu investasi yang memberikan return dengan tingkat tertentu dengan resiko yang medium. Oleh karena itu, sekarang ini banyak perusahaan sekuritas yang menawarkan produk reksa dana sebagai alternatif investasi. Reksa dana ini sendiri bukan hanya popular di pasaran Indonesia tetapi juga di dunia, yang mana lebih dikenal dengan istilah Mutual Fund. Menurut data dari Shazad, et al, 2010), nilai kelolaan reksa dana saat ini tidak hanya mencapai jutaan atau miliaran dollar tetapi triliunan dollar. Sedangkan di Indonesia sendiri, menurut data dari Bapepam-LK, reksa dana terus berkembang sejak tahun 1995 sampai sekarang telah mencapai angka triliunan rupiah. Selain itu, dari jumlah produk reksa dana yang beroperasi per akhir Desember 2009, sudah mencapai 673 buah dengan berbagai variasi tipe reksa dana mulai dari reksa dana pendapatan 
tetap, reksa dana saham, reksa dana campuran, reksa dana pasar uang, reksa dana syariah, dan reksa dana indeks. Tipe reksa dana inipun mempunyai tingkat resiko yang berbeda-beda dengan tingkat return yang berbeda-beda pula. Walaupun resiko reksa dana lebih kecil daripada berinvestasi saham secara langsung tapi ada baiknya bila investor tetap berhati-hati dalam berinvestasi, seperti dengan cara mengumpulkan informasi yang dapat diperoleh dari hasil research, dari prospectus reksa dananya, ataupun dari kinerja historis reksa dana tersebut.

Karena pentingnya informasi mengenai kinerja reksa dana dalam pengambilan keputusan untuk berinvestasi, maka penulis tertarik untuk melakukan penelitian atas kinerja 15 reksa dana saham terbaik 2010 menurut Majalah Investor (terbit bulan Maret 2010, datanya berdasarkan NAB 2009). Penelitian ini akan mengevaluasi 15 reksa dana saham terbaik tersebut untuk periode berikutnya di tahun 2011 (menggunakan data NAB reksa dana di tahun 2010). Hal ini dilakukan untuk mengetahui reksa dana mana yang dapat bertahan sebagai reksa dana terbaik selama 2 periode. Pentingnya menilai kinerja reksa dana lebih dari satu tahun telah diungkapkan oleh Sipra (2005) dalam penelitiannya. Dia menyatakan bahwa return yang dihasilkan oleh berbagai reksa dana bervariasi untuk setiap periodenya. Suatu reksa dana mungkin saja mempunyai kinerja yang bagus untuk satu tahun tetapi tidak untuk tahun yang berikutnya. Suatu reksa dana dapat dikatakan superior jika dapat mempertahankan konsistensi kinerjanya untuk beberapa periode. Penelitian ini difokuskan pada reksa dana saham karena jenis reksa dana inilah yang beresiko paling tinggi di antara tipe reksa dana lainnya sehingga mempermudah investor dalam pengambilan keputusan. Secara keseluruhan, paper ini akan terbagi ke dalam 5 tahapan, di mana tahap ke-2, akan membahas beberapa literature review yang berkaitan dengan penelitian ini. Tahap ke-3, menyajikan data dan metodologi penelitian yang digunakan dalam mengevaluasi kinerja, di mana hasil dari penelitian ini akan dibahas pada Tahap selanjutnya. Pada akhirnya ditarik kesimpulan untuk hasil penelitian tersebut.

\section{Kajian Teori}

Evaluasi terhadap kinerja reksa dana bukanlah hal yang baru tetapi sebenarnya telah ada sejak beberapa dekade yang lalu. Menurut Reilly \& Brown (2007), sebelum tahun 1960, para investor mengevaluasi kinerja portofolio aset pada umumnya hanya berdasarkan tingkat return. Mereka bukan tidak mengerti akan pentingnya risiko terhadap investasi namun mereka belum tahu bagaimana mengukur risiko tersebut secara benar. Di tahun 1965, Treynor mengembangkan metode evaluasi reksa dana yang lebih kompleks untuk pertama kalinya di mana mencakup penghitungan risiko dari portofolio. Treynor mengasumsikan bahwa ada dua komponen risiko, yaitu risiko yang dihasilkan dari fluktuasi market dan risiko yang berasal dari fluktuasi yang unik yang ada dalam portofolio aset. Untuk mengidentifikasi risiko karena fluktuasi market, diperkenalkan characteristic line, yang mendeskripsikan hubungan antara tingkat return dari suatu portofolio aset dan tingkat return dari portofolio market. Slope dari Characteristic line inilah yang mengukur relative volatility suatu return portofolio terhadap market. Slope dari portofolio ini lebih dikenal sebagai koefisien beta. Beta adalah systematic risk suatu portofolio yang tidak dapat diminimalisasi dengan diversifikasi. Semakin tinggi beta, maka suatu portofolio lebih sensitif terhadap return pasar dan dapat dikatakan memiliki risiko pasar yang lebih besar.

Setahun kemudian Sharpe(1966) memperkenalkan metode kompleks lainnya dalam pengevaluasian kinerja reksa dana. Metode ini hampir sama dengan yang diperkenalkan oleh Treynor, namun Sharpe memasukkan resiko keseluruhan (total risk) dari suatu portofolio dengan cara menghitung standard deviasi dari return yang ada daripada hanya mempertimbangkan systematic risk (beta). Pada prinsipnya dalam suatu portofolio terkandung dua macam risiko yaitu systematic dan unsystematic risk. Unsystematic risk adalah risiko spesifik yang ada dalam suatu portofolio dan dapat diminimalisasikan dengan diversifikasi. Sedangkan systematic risk adalah risiko yang berkaitan dengan riskio pasar seperti risiko dari suku bunga, inflasi, resesi, yang mempengaruhi portofolio dan tidak dapat diminimalisasi dengan cara diversifikasi. 
Sharpe (1996) menggunakan standar deviasi dari return sebagai alat ukur terhadap total risk dari suatu portofolio, sehingga metode evaluasi dari Sharpe berdasarkan pada kinerja tingkat return dan diversifikasi. Sedangkan Treynor menggunakan beta (systematic risk). Untuk portofolio yang telah terdiversifikasi secara baik, tanpa unsystematic risk, maka Metode Treynor dan Sharpe akan menghasilkan rangking yang hampir sama karena risiko yang tersisa pada portofolio tersebut hanya risiko sistematis. Atau, untuk portofolio yang tidak terdiversifikasi secara baik, akan mempunyai rangking yang lebih tinggi untuk Treynor, namun rangking yang lebih rendah untuk Sharpe. Oleh karena itu, kedua metode evaluasi ini adalah metode yang saling melengkapi dalam pengukuran kinerja suatu portofolio yang dalam hal ini adalah reksa dana (Reilly \& Brown, 2007).

Kedua metode pengukuran kinerja ini (Sharpe, 1966; Treynor, 1965) menggunakan prinsip yang sama dalam menilai apakah suatu reksa dana mempunyai kinerja yang baik, yaitu apabila kinerja portofolio melebihi kinerja market. Selanjutnya, Jensen (1968) memperkenalkan metode evaluasi yang hampir sama dengan kedua metode tersebut. Jensen mengukur berdasarkan CAPM (Capital Asset Pricing Model). Namun, pengukuran Jensen ini mempunyai kelebihan jika dibandingkan dengan Treynor dan Sharpe. Salah satu kelebihan tersebut adalah hasil penghitungannya lebih mudah untuk diinterpretasi, contohnya jika Jensen alpha adalah 0,02 mengindikasikan bahwa manajer investasi dapat menghasilkan tingkat return yang lebih besar $2 \%$ daripada return yang diharapkan untuk tingkat risiko tertentu.

Sejak diperkenalkannya metode evaluasi oleh Treynor, Sharpe, dan Jensen, maka berkembanglah metode-metode evaluasi lainnya yang lebih complex. Seperti, Christopherson, Ferson \& Glassman (1998) yang mengklaim bahwa penting untuk mempertimbangkan informasi publik yang tersedia untuk investor pada saat return dihasilkan, yang berarti membiarkan perkiraan kinerja dan risiko mempunyai perbedaan waktu. Metode ini biasa juga disebut dengan pengukuran kinerja dengan conditional models. Peneliti yang lain yaitu Otten \& Bams (2004) memperkenalkan metode pengukuran yang mereka percaya lebih komprehensif dengan tujuan dapat menyajikan model yang terbaik untuk mengukur kinerja dari reksa dana. Yang mana tahap pertama, menggunakan metode CAPM (basic single factor), yang diikuti dengan pengukuran yang mempertimbangkan variabel lainnya seperti size, book-to-market, momentum dan bond index. Untuk mencapai pengukuran yang mereka klaim lebih baik, maka mereka mengusung the statistical and economic relevance dari berbagai range spesifikasi model.

Disebabkan oleh banyaknya metode pengukuran dan evaluasi kinerja dari reksa dana maka hal ini bisa menimbulkan kerancuan untuk para akademisi, investor maupun praktisi dalam menentukan metode apa yang akan mereka gunakan dalam mengevaluasi kinerja suatu reksa dana. Namun, mengingat tujuan dari penelitian ini yaitu untuk memberikan informasi yang dapat digunakan oleh investor Indonesia yang belum familiar dengan dunia pasar modal, maka penelitian ini akan berfokus hanya pada metode evaluasi yang basic seperti Sharpe, Treynor, dan Jensen. Hal ini untuk memudahkan mereka dalam pengukuran dan evaluasi kinerja reksa dana sehingga dapat mendorong mereka untuk aktif berpartisipasi dalam pasar modal.

\section{METODOLOGI PENELITIAN}

Studi ini mengevaluasi 15 kinerja reksa dana saham terbaik menurut majalah investor edisi 2010. Di bawah ini terlampir 15 reksa dana tersebut: 
Tabel 1 Kinerja Reksadana

\begin{tabular}{ll}
\hline \multicolumn{1}{c}{ Reksa Dana } & \multicolumn{1}{c}{ Manajer Investasi } \\
\hline Manulife Saham Andalan & Manulife Aset Manajemen Indonesia \\
Mandiri Investa Atraktif & Mandiri Manajemen Investasi \\
First State Indoequity Sectoral Fund & First State Investment Indonesia \\
Panin Dana Prima & Panin Sekuritas Tbk \\
Trim Kapital Plus & Trimegah Securities Tbk \\
GMT Dana Ekuitas & GMT Aset manajemen \\
Pratama Saham & Pratama Capital Indonesia \\
Schroder Dana Prestasi Plus & Schroder Investment Management Indonesia \\
Si Dana Saham & Batavia Prosperindo Aset manajemen \\
Schroder Dana Istimewa & Schroder Investment Management Indonesia \\
Rencana Cerdas & Ciptadana Asset Management \\
Fortis Pesona/BNP Paribas Pesona & BNP Paribas Investment Partners \\
Fortis Ekuitas/BNP Paribas Ekuitas & BNP Paribas Investment Partners \\
Manulife dana saham & Manulife Aset Manajemen Indonesia \\
Panin Dana Maksima & Panin Sekuritas Tbk \\
\hline
\end{tabular}

Namun, karena keterbatasan informasi, maka hanya 14 reksa dana yang akan dievaluasi. Reksa dana yang tidak diperoleh datanya adalah Pratama Saham yang dikelola oleh Pratama Capital Indonesia. Keterangan lainnya, ada dua reksa dana yang namanya telah berubah yaitu Fortis Pesona menjadi BNP Paribas Pesona, begitu pula dengan Fortis Ekuitas berubah menjadi BNP Paribas Ekuitas. Data yang akan dievaluasi adalah data harian NAB dari keempat belas reksa dana tersebut. Data ini berupa data sekunder, karena merupakan data yang telah dikelola oleh website: kontan.co.id. Data akan dievaluasi dan dianalisa untuk periode setahun mulai 1 Januari 2010 sampai dengan 31 Desember 2010. Selain data NAB, paper ini juga akan menggunakan return IHSG sebagai return market dan $\mathrm{BI}$ rate sebagai risk-free rate.

Penelitian ini akan berfokus pada beberapa tahapan. Tahap pertama, mencari return ke 14 reksa dana, IHSG dan BI rate untuk periode setahun, setelah itu kinerja reksa dana akan dievaluasi menggunakan metode Sharpe, Treynor untuk menentukan rangking reksa dana terbaik yang dapat outperform return market. Rangking return reksa dana dari kedua metode tersebut juga akan dibandingkan untuk memperoleh keterangan mana reksa dana yang telah terdiversifikasi secara baik. Selain kedua metode tersebut, evaluasi lain yang akan digunakan adalah Jensen performance. Hasil evaluasi Jensen untuk menentukan manajer investasi yang telah mengelola reksa dana dengan baik.

\section{HASIL DAN PEMBAHASAN}

Untuk mengevaluasi kinerja reksa dana tersebut, maka ada beberapa tahapan analisis yang akan dilalui yaitu sebagai berikut:

\section{Mean Retun, Variance, Standard Deviation and Beta}

Menghitung return masing-masing reksa dana sesuai dengan formula yang telah dijabarkan oleh Reilly \& Brown, 2006. 


$$
E(R i)=\sum_{i=1}^{n} R i . P i
$$

Di mana:

$$
\begin{array}{ll}
E(R i) & =\text { Expected Return (mean) } \\
n & =\text { Banyaknya data } \\
i & =\text { Tahun awal } \\
R i & =\text { Return realisasi } \\
P i & =\text { Return Probabilitas }
\end{array}
$$

Menghitung return IHSG, menggunakan formula yang sama dengan di atas. Kemudian dilakukan perhitungan standar deviasi untuk masing-masing reksa dana dan IHSG yang diperoleh dari square root variance dengan formula sebagai berikut:

$$
\begin{gathered}
\text { Vartance }\left(\sigma^{2}\right)=\sum_{i=1}^{n} P_{i}\left(R_{i}-E\left(R_{i}\right)\right]^{2} \\
\text { StandardDevtation }(\sigma)=\sqrt{\sum_{i=1}^{n} P_{i}\left[R_{i}-E\left(R_{i}\right)\right]^{2}}
\end{gathered}
$$

Di mana :

$(\sigma) \quad=$ Standard Deviasi

$E(R i)=$ Expected Return (mean)

$n \quad=$ Banyaknya data

$i \quad=$ Tahun awal

Ri $\quad=$ Return realisasi

$\mathrm{Pi} \quad=$ Return Probabilitas

dan Beta $(\beta)$ menggunakan rumus :

$$
\operatorname{Beta}(\beta)=\frac{\operatorname{Cov}(R i ; R m)}{\operatorname{Var}(R m)}
$$

Di mana :

$$
\begin{array}{ll}
(\beta) & =\text { Beta } \\
R i & =\text { Return realisasi } \\
R m & =\text { Return market }
\end{array}
$$

\section{Performance Evaluation dengan Metode Sharpe dan Treynor}

Menganalisis kinerja masing-masing reksa dana menggunakan metode Sharpe dengan rumus sebagai berikut

$$
S_{i}=\frac{\overline{R_{i}}-\overline{P F R}}{\sigma_{i}}
$$


Di mana :

$$
\begin{array}{ll}
\frac{S_{i}}{\overline{R i}} & =\text { Sharpe Ratio } \\
\overline{R F} R & =\text { Rata-rata return realisasi } \\
\sigma & =\text { Standatard Deviation }
\end{array}
$$

Tabel 2 Hasil Perhitungan Kinerja Keempat Belas Reksa Dana Menggunakan Sharpe Evaluation

\begin{tabular}{lccccc}
\hline \multicolumn{1}{c}{ Reksa Dana } & $\overline{R i}$ & $\overline{R F} R$ & $\sigma$ & $\begin{array}{c}\text { Sharpe } \\
\text { Ratio }\end{array}$ & $\begin{array}{c}\text { outperform/ } \\
\text { underperform the market }\end{array}$ \\
\hline Manulife Saham Andalan & 0.00134 & 0.00018 & 0.01305 & 0.08877 & underperform \\
Mandiri Investa Atraktif & 0.00124 & 0.00018 & 0.01251 & 0.08499 & underperform \\
First State Indoequity Sectoral Fund & 0.00117 & 0.00018 & 0.01396 & 0.07088 & underperform \\
Panin Dana Prima & 0.00204 & 0.00018 & 0.01324 & 0.14040 & outperform \\
Trim Kapital Plus & 0.00152 & 0.00018 & 0.01587 & 0.08457 & underperform \\
GMT Dana Ekuitas & 0.00130 & 0.00018 & 0.01319 & 0.08476 & underperform \\
Schroder Dana Prestasi Plus & 0.00122 & 0.00018 & 0.01313 & 0.07928 & underperform \\
Si Dana Saham & 0.00115 & 0.00018 & 0.00941 & 0.10290 & underperform \\
Schroder Dana Istimewa & 0.00236 & 0.00018 & 0.04848 & 0.04507 & underperform \\
Rencana Cerdas & 0.00144 & 0.00018 & 0.01354 & 0.09292 & underperform \\
Fortis Pesona & 0.00134 & 0.00018 & 0.01301 & 0.08946 & underperform \\
Fortis Ekuitas & 0.00139 & 0.00018 & 0.01354 & 0.08909 & underperform \\
Manulife dana saham & 0.00121 & 0.00018 & 0.01246 & 0.08302 & underperform \\
Panin Dana Maksima & 0.00293 & 0.00018 & 0.01232 & 0.22346 & outperform \\
IHSG & 0.00158 & 0.00018 & 0.01266 & 0.11072 & underperform \\
\hline
\end{tabular}

Hasil ini menunjukkan bahwa berdasarkan perhitungan Sharpe, hanya ada dua reksa dana yang kinerjanya melebihi kinerja pasar yaitu Panin Dana Prima dan Panin Dana Maksima. Menganalisis kinerja masing-masing reksa dana menggunakan metode Treynor dengan rumus sebagai berikut:

$$
T=\frac{\overline{R_{t}}-\overline{R F R}}{\beta_{i}}
$$

Di mana:

$$
\begin{array}{ll}
\frac{T}{R i} & =\text { Metode Treynor } \\
\overline{R F} R & =\text { Rata-rata return realisasi } \\
\beta & =\text { Beta-rata risk-free }
\end{array}
$$


Tabel 3 Hasil Perhitungan Kinerja Keempat Belas Reksa Dana Menggunakan Treynor Evaluation

\begin{tabular}{|c|c|c|c|c|c|}
\hline Reksa Dana & $\overline{R i}$ & $\overline{R F} R$ & Beta $(\beta)$ & $\begin{array}{l}\text { Treynor } \\
\text { Ratio }\end{array}$ & $\begin{array}{l}\text { outperform/ } \\
\text { underperform the } \\
\text { market }\end{array}$ \\
\hline Manulife Saham Andalan & 0.00134 & 0.00018 & 1.00502 & 0.00115 & underperform \\
\hline Mandiri Investa Atraktif & 0.00124 & 0.00018 & 0.93900 & 0.00113 & underperform \\
\hline First State Indoequity Sectoral Fund & 0.00117 & 0.00018 & 1.07835 & 0.00092 & underperform \\
\hline Panin Dana Prima & 0.00204 & 0.00018 & 0.96304 & 0.00193 & Outperform \\
\hline Trim Kapital Plus & 0.00152 & 0.00018 & 1.05883 & 0.00127 & underperform \\
\hline GMT Dana Ekuitas & 0.00130 & 0.00018 & 0.96873 & 0.00115 & underperform \\
\hline Schroder Dana Prestasi Plus & 0.00122 & 0.00018 & 1.01025 & 0.00103 & underperform \\
\hline Si Dana Saham & 0.00115 & 0.00018 & 0.49988 & 0.00194 & Outperform \\
\hline Schroder Dana Istimewa & 0.00236 & 0.00018 & 1.31084 & 0.00167 & Outperform \\
\hline Rencana Cerdas & 0.00144 & 0.00018 & 1.03613 & 0.00121 & underperform \\
\hline Fortis Pesona & 0.00134 & 0.00018 & 0.99325 & 0.00117 & underperform \\
\hline Fortis Ekuitas & 0.00139 & 0.00018 & 1.04259 & 0.00116 & underperform \\
\hline Manulife dana saham & 0.00121 & 0.00018 & 0.95776 & 0.00108 & underperform \\
\hline Panin Dana Maksima & 0.00293 & 0.00018 & 0.83999 & 0.00328 & Outperform \\
\hline IHSG & 0.00158 & 0.00018 & 1 & 0.00140 & \\
\hline
\end{tabular}

Hasil ini menunjukkan bahwa berdasarkan perhitungan Treynor, hanya ada empat reksa dana yang kinerjanya melebihi kinerja pasar yaitu Panin Dana Prima dan Si Dana Saham, Schroder Dana Istimewa dan Panin Dana Maksima.

\section{Ranking Performance berdasarkan Sharpe dan Treynor}

Hasil evaluasi kedua metode Sharpe dan Treynor akan diurutkan berdasarkan rangking untuk menentukan reksa dana yang terdiversifikasi dengan baik. Reksa dana yang terdiversifikasi dengan baik akan memperoleh rangking yang sama untuk kedua metode evaluasi tersebut.

Tabel 4 Hasil Evaluasi Kedua Metode Sharpe dan Treynor

\begin{tabular}{lcccc}
\hline Reksa Dana & $\begin{array}{l}\text { Sharpe } \\
\text { Ratio }\end{array}$ & Rangking & $\begin{array}{l}\text { Treynor } \\
\text { Ratio }\end{array}$ & Rangking \\
\hline Panin Dana Maksima & 0.22346 & 1 & 0.00328 & 1 \\
Panin Dana Prima & 0.14040 & 2 & 0.00193 & 3 \\
IHSG & 0.11072 & 3 & 0.00140 & 5 \\
Si Dana Saham & 0.10290 & 4 & 0.00194 & 2 \\
Rencana Cerdas & 0.09292 & 5 & 0.00121 & 7 \\
Fortis Pesona & 0.08946 & 6 & 0.00117 & 8 \\
Fortis Ekuitas & 0.08909 & 7 & 0.00116 & 9 \\
Manulife Saham Andalan & 0.08877 & 8 & 0.00115 & 11 \\
Mandiri Investa Atraktif & 0.08499 & 9 & 0.00113 & 12 \\
GMT Dana Ekuitas & 0.08476 & 10 & 0.00115 & 10 \\
Trim Kapital Plus & 0.08457 & 11 & 0.00127 & 6 \\
Manulife dana saham & 0.08302 & 12 & 0.00108 & 13 \\
Schroder Dana Prestasi Plus & 0.07928 & 13 & 0.00103 & 14 \\
First State Indoequity Sectoral Fund & 0.07088 & 14 & 0.00092 & 15 \\
Schroder Dana Istimewa & 0.04507 & 15 & 0.00167 & 4 \\
\hline
\end{tabular}

Berdasarkan urutan rangking di atas, hanya ada dua reksa dana yang memiliki rangking yang sama yaitu Panin Dana Maksima di posisi pertama dan GMT Dana Ekuitas di posisi ke sepuluh. Ini mengindikasikan bahwa kedua reksa dana tersebut telah terdiversifikasi secara baik atau dengan kata lain unsystematic risk keduanya telah dieliminasi. 


\section{Performance Evaluation dengan metode Jensen}

Menganalisis kinerja masing-masing reksa dana menggunakan metode Jensen dengan rumus sebagai berikut:

$$
\alpha=(\overline{R i}-\overline{R F R})-\beta(\overline{R m}-\overline{R F R})
$$

Di mana :

$$
\begin{array}{ll}
\frac{\alpha}{R i} & =\text { Alpha } \\
\overline{R F} R & =\text { Rata-rata return realisasi } \\
\beta & =\text { Beta-rata risk-free } \\
\overline{R m} & =\text { Rata-rata Return market }
\end{array}
$$

Tabel 5 Hasil Perhitungan Kinerja Keempat Belas Reksa Dana Menggunakan Jensen Evaluation

\begin{tabular}{lccc}
\hline Reksa Dana & $\overline{(R i}-\overline{R F R}$ & $\beta(\overline{R m}-\overline{R F R})$ & Jensen Ratio (a) \\
\hline Manulife Saham Andalan & 0.00116 & 0.00141 & -0.00025 \\
Mandiri Investa Atraktif & 0.00106 & 0.00132 & -0.00025 \\
First State Indoequity Sectoral Fund & 0.00099 & 0.00151 & -0.00052 \\
Panin Dana Prima & 0.00186 & 0.00135 & 0.00051 \\
Trim Kapital Plus & 0.00134 & 0.00148 & -0.00014 \\
GMT Dana Ekuitas & 0.00112 & 0.00136 & -0.00024 \\
Schroder Dana Prestasi Plus & 0.00104 & 0.00142 & -0.00038 \\
Si Dana Saham & 0.00097 & 0.00070 & 0.00027 \\
Schroder Dana Istimewa & 0.00218 & 0.00184 & 0.00035 \\
Rencana Cerdas & 0.00126 & 0.00145 & -0.00019 \\
Fortis Pesona & 0.00116 & 0.00139 & -0.00023 \\
Fortis Ekuitas & 0.00121 & 0.00146 & -0.00026 \\
Manulife dana saham & 0.00103 & 0.00134 & -0.00031 \\
Panin Dana Maksima & 0.00275 & 0.00118 & 0.00158 \\
\hline
\end{tabular}

Hasil ini menunjukkan bahwa berdasarkan perhitungan Jensen, hanya ada empat reksa dana yang mempunyai alpha $(\alpha)$ positif, dan secara berurut adalah sebagai berikut: Panin Dana Maksima, Panin Dana Prima, Schroder Dana Istimewa dan di posisi terakhir Si Dana Saham. Reksa dana yang menunjukkan $\alpha$ positif yang terbesar adalah Panin Dana Maksima yaitu sebesar 0.00158. Hal ini mengindikasikan bahwa manajer investasi ini berhasil untuk mengelola reksa dananya dengan tingkat return lebih besar $0.158 \%$ per hari yang seharusnya diterima untuk tingkat risiko yang terdapat dalam reksa dana tersebut.

\section{PENUTUP}

Setelah menilai kinerja empat belas (14) reksa dana saham terbaik menurut majalah Investor Maret 2010, ditemukan bahwa hanya beberapa reksa dana yang memiliki kinerja yang masih di atas kinerja pasar. Kinerja reksa dana dievaluasi berdasarkan periode berikutnya yaitu data kinerja tahun 2010. Menurut evaluasi Sharpe, hanya ada dua reksa dana yang kinerjanya di atas pasar yaitu Panin Dana Prima dan Panin Dana Maksima. Sedangkan menurut perhitungan Treynor ada empat reksa dana terbaik yaitu Panin Dana Prima, Si Dana Saham, Schroder Dana Istimewa dan Panin Dana Maksima. Setelah dilakukan rangking untuk kedua metode evaluasi (Sharpe and Treynor) maka hanya ada dua reksa dana yang memiliki rangking yang sama yang berarti reksa dana tersebut telah terdiversifikasi 
dengan baik yaitu Panin Dana Maksima dan GMT Ekuitas. Menurut Jensen, hanya ada empat reksa dana yang memiliki alpha yang positif, di mana posisi pertama ditempati oleh Panin Dana Maksima, diikuti oleh Panin Dana Prima, Schroder Dana Istimewa, dan Si Dana Saham. Hasil dari evaluasi tahun 2010 merekomendasikan dua reksa dana yang terbaik yaitu Panin Dana Maksima dan Panin Dana Prima. Kedua reksa dana ini menghasilkan kinerja yang selalu outperform the market untuk semua metode evaluasi yang dilakukan dalam penelitian ini. Kedua reksa dana tersebut juga dapat mempertahankan kinerja mereka selama dua tahun berturut-turut yaitu di tahun 2009 (berdasarkan majalah investor) dan 2010 (berdasarkan penelitian) ini.

\section{DAFTAR PUSTAKA}

Christopherson, J., Ferson, W., \& Glassman, D. (1998). Conditioning manager Alphas on economic information: another look at the persistence of performance. Review of Financial Studies. 11, pp. $111-142$.

Jensen, M. C. (1968). The performance of mutual funds in the period 1945 - 1964. Journal of Finance. 23, no. 2, pp. $389-416$.

Otten, R., \& Bams, D. (2004). How to measure mutual fund performance: economic versus statistical relevance. Journal of Accounting and Finance. Vol. 44, pp. 203 - 222.

Reilly, F. K., \& Brown, K. C. (2006). Investment Analysis and Portfolio Management. USA: Thomson South-Western.

Sadewa, P. Y. (2009). Kredibilitas bursa saham perlu ditingkatkan. Danareksa Research Institute, accessed $02^{\text {th }}$ April 2009 from http://www.danareksa-research.com/economy/medianewspaper/242-kredibilitas-bursa-saham-perlu-ditingkatkan

Shahzad, A., Khilji, B. A., Ahmed, I., Asghar, N.A., \& Ali, J. (2010). Performance evaluation of mutual funds in Pakistan for the period of 2004-2008. Interdisciplinary Journal of Contemporary Research in Business. Vol. 2, No. 4, accessed $02^{\text {th }}$ February 2011 from http://proquest.umi.com/pqdweb?index $=0 \&$ did $=2163980921 \&$ SrchMode $=2 \&$ sid $=1 \& \mathrm{Fmt}=6 \&$ VInst=PROD\&VType=PQD\&RQT $=309 \&$ VName $=$ PQD\&TS=1298833940\&clientId $=68814$

Sharpe, W. F. (1966). Mutual fund performance. Journal of Business. 39, pp. 119 - 138.

Sipra, N. (2005). A glance at mutual funds in Pakistan. LUMS Paper.

Treynor, J. L. (1965). How to rate management of investment funds. Harvard Business Review. 43, no.1. pp. $63-75$. 